\title{
CURRENT SCENARIO OF NIPAH VIRUS: A REVIEW
}

SWATHI. $\mathbf{S}^{1}$, NAVEEN KUMAR. $\mathbf{C}^{2 *}$, SRIKUMAR. $\mathbf{R}^{3}$, VIJAYAKUMAR. $\mathbf{R}^{4}$, THIRUSELVAKUMAR. $D^{5}$ AND PRABHAKAR REDDY. $\mathrm{E}^{6}$

1: Assistant Professor, Department in Microbiology, Sri Lakshmi Narayana Institute of Medical Sciences, Puducherry

2: Associate Professor in Microbiology, Sri Lakshmi Narayana Institute of Medical Sciences, Puducherry

3: Research Associate in Center for Research, Sri Lakshmi Narayana Institute of Medical Sciences, Puducherry

4: Professor in Physiology, Sri Lakshmi Narayana Institute of Medical Sciences, Puducherry 5: Associate Professor, Department of Community Medicine, Sri Lakshmi Narayana Institute of Medical Sciences, Puducherry

6: Professor in Biochemistry, Bharath Medical College and Hospital, Chennai and Affiliated to BIHER

*Corresponding Author: Dr. Naveen Kumar. C: E Mail: navin.mmb@gmail.com Received 16 ${ }^{\text {th }}$ Oct. 2020; Revised $15^{\text {th }}$ Nov. 2020; Accepted $11^{\text {th }}$ Dec. 2020; Available online $1^{\text {st }}$ Jan. 2021 https://doi.org/10.31032/IJBPAS/2021/10.1.1007

\section{ABSTRACT}

Nipah virus (NiV) is belongs to genus of Henipavirus, which is a zoonotic and deadly virus with a high mortality rate that has affected many of the countries in the past and present. According to the Centers for Disease Control and Prevention (CDC), many economically deprived countries such as Africa and South Asia are also at high risk for future outbreaks. The first case of NiV was reported in 1998 at Malaysia and almost two decades later, the first case was reported in India at 2001. As many developing countries are not properly equipped to fight the infection and the vaccine against $\mathrm{NiV}$, it is vital to properly educate the health systems. The aim of this review is to provide epidemiological conditions as well as to understand the presentation, transmission routes and the various new diagnostic methods and prevention of this deadly virus.

Keywords: Nipah virus (NiV), Centers for Disease Control and Prevention (CDC), Mode of Transmission 


\section{INTRODUCTION}

The first case of Nipah virus (NiV) infection was initially reported in September 1998 near Ipoh, West Malaysia. Over the several months, several clusters of infections were reported over various regions such as near Sikamet and Bukit Pelandok [1]. Four patients were tested primarily, assumed to be Japanese B Encephalitis was shown positive. Many of them died, the assessed victims were reports of sick pigs with a barking cough. The clinical conditions of Nipah virus were not typical of Japanese B Encephalitis [23]. The virus was first isolated and classified based on its appearance at March 1999 and grouped in a Paramyoviridae virus [4]. The second outbreak occurred in India 2001 in Meherpur, Bangladesh, and Siliguri, West Bengal, India. Laboratory investigations were failed to properly identify the organisms. After several decades, the outbreak in 2014, the Philippines National Epidemiology Center was screened the causative agent of deaths in Mindanao, Philippines. The investigation was found positive for antibodies IgM against $\mathrm{NiV}$ in 03 patients. A fatality rate about 53\% was observed during that particular outbreak in Philippines and 82\% had acute encephalitis were reported [5]. Last year at May 2018, an major outbreak of $\mathrm{NiV}$ was reported in the south India state of Kerala. The epidemic spread through human-to-human transmission by droplet infection. About 17 deaths by NiV were announced by the State of Kerala at the end of June 2018 [6].

The National Centre for Disease Control India (NCDC) stated that a suspected case of a person from a community affected by a NiV infection, based on the following clinical conditions, such as;

a) Acute Fever with new onset of altered mental status or seizure and/or

b) Acute Fever with severe headache and/or

c) Acute Fever with Cough or shortness of breath

A confirmed case based on the laboratory investigations of Nipah infection by polymerase chain reaction (PCR). Various samples were tested such as respiratory secretions (throat swab), urine and cerebrospinal fluid [7]. Current decade threatens about the $\mathrm{NiV}$, according to the Centers for Disease Control and Prevention (CDC) many economically privileged countries had more chance of spread of this disease due to the limited resources and infrastructure and to prevent. To avoid major fatality rate by proper understanding of the previous outbreaks and setting up of appropriate protocols which can helps to protect against future occurrences of NiV. The outbreaks of historical review of the NiV for past several decades explained in the Table 1. 
Table 1

\begin{tabular}{|c|c|c|c|c|c|c|c|}
\hline $\begin{array}{l}\text { S. } \\
\text { No }\end{array}$ & Month -Year & Country & $\begin{array}{l}\text { No. of } \\
\text { Cases }\end{array}$ & $\begin{array}{l}\text { No. of } \\
\text { Deaths }\end{array}$ & $\begin{array}{c}\text { Fatality } \\
\text { Rate } \\
\text { in } \% \\
\end{array}$ & $\begin{array}{c}\text { Mode of } \\
\text { Transmission }\end{array}$ & Source \\
\hline 1 & June-1999 & Malaysia & 276 & 106 & 38 & Sick Pig to Humans & Direct Contact \\
\hline 2 & Feb-2001 & $\begin{array}{c}\text { India (West } \\
\text { Bengal) }\end{array}$ & 66 & 45 & 68 & Human to Human & Air Droplets \\
\hline 3 & May-2001 & Bangladesh & 13 & 09 & 69 & Fruit Bats to Human & Contaminated Fruit \\
\hline 4 & Jan-2003 & Bangladesh & 12 & 08 & 67 & Fruit Bats to Human & Saliva of Fruit bat \\
\hline 5 & Jan-2004 & Bangladesh & 31 & 23 & 74 & Fruit Bats to Human & Urine of Fruit bat \\
\hline 6 & Apr-2004 & Bangladesh & 36 & 27 & 75 & Human to Human & Air Droplets \\
\hline 7 & Mar-2005 & Bangladesh & 12 & 11 & 92 & Human to Human & Air Droplets \\
\hline 8 & Feb-2007 & Bangladesh & 07 & 03 & 43 & Human to Human & Air Droplets \\
\hline 9 & Apr-2007 & Bangladesh & 11 & 06 & 96 & Human to Human & Air Droplets \\
\hline 10 & Apr-2007 & $\begin{array}{c}\text { India (West } \\
\text { Bengal) } \\
\end{array}$ & 05 & 05 & 100 & Human to Human & Air Droplets \\
\hline 11 & Feb-2008 & Bangladesh & 04 & 04 & 100 & Human to Human & Air Droplets \\
\hline 12 & Apr-2008 & Bangladesh & 07 & 05 & 71 & Human to Human & Air Droplets \\
\hline 13 & Jan-2009 & Bangladesh & 04 & 01 & 75 & Human to Human & Air Droplets \\
\hline 14 & Mar-2010 & Bangladesh & 16 & 14 & 88 & Human to Human & Air Droplets \\
\hline 15 & Feb-2011 & Bangladesh & 44 & 40 & 91 & Human to Human & Air Droplets \\
\hline 16 & Feb-2012 & Bangladesh & 12 & 10 & 83 & Human to Human & Air Droplets \\
\hline 17 & Apr-2013 & Bangladesh & 24 & 21 & 88 & Human to Human & Air Droplets \\
\hline 18 & Apr-2014 & Philippines & 17 & 09 & 53 & Human to Human & Air Droplets \\
\hline 19 & Mar-2014 & Bangladesh & 18 & 09 & 50 & Human to Human & Air Droplets \\
\hline 20 & Feb-2015 & Bangladesh & 09 & 06 & 67 & Human to Human & Air Droplets \\
\hline 21 & Мay-2018 & India (Kerala) & 13 & 11 & 85 & Fruit Bats to Human & Contaminated Fruit \\
\hline 22 & June-2019 & India (Kerala) & 86 & 17 & 20 & Human to Human & Air Droplets \\
\hline \multicolumn{3}{|c|}{ Total } & 723 & 390 & 54 & & \\
\hline
\end{tabular}

\section{METHOD}

The present article based on collective study of previous publications about NiV reviews on Google Scholar. This study explains the consolidate details about the NiV.

\section{NIPAH Virus?}

The history of $\mathrm{NiV}$ starts from March 1999; University of Malaysia first carried out analysis of the virus. The virus was isolated and studied from the cerebrospinal fluid sample of a patient suffering from encephalitis. The name origination of the Nipah virus was proposed from the location of the Kampung Sungai Nipah at Malaysia, were the first source of the sample obtained [4]. Nipah virus characteristic were similar to Paramyxoviridae virus, it has been identified by electron microscopy. The antibody activity of the other Paramyxovirus, were shown to be negative reactivity to $\mathrm{NiV}$. NiV was seen circular, pleomorphic about $1900 \mathrm{~nm}$ with various proteins such as Matrixprotein (M), Polymersaeprotein (L), Glycoprotein (G), Fusionprotein (F), Nucleoprotein (N) and Phosphoprotein (P). The pleomorphic factors help to change the spherical to filamentous form. Two major strains were one at NiV Malaysia and another one at NiV Bangladesh [8]. 


\section{Transmission of NIV?}

The main reservoir of $\mathrm{NiV}$ is Pteropus, Fruit bats [9-11]. The investigations surprise was the infected bats have not show any symptoms of the disease by NiV. Greater than 23 species of fruit bats have been found to be reservoirs of $\mathrm{NiV}$. The infected fruit bats were act as a host for the virus and which naturally infects the dogs, horses, pigs, cats, including humans $[5,12]$. Urine or saliva of the infected host was considering the mode of transmission. Other than the fruit bat guinea pigs, ferrets, and African green monkeys are also act as host for NiV. NiV had a special character such as ephrin B2/B3 molecules which helps the virus to enter the host cell in a wide tropism, while comparing the other paramyxoviruses [13].

Humans were infected by bats to human through an intermediate animal host or direct bat-to-human transmission. Bangladesh and India of several outbreaks reveals the Human-to-human transmissions cases [14-15]. Various mode of transmission explain in the picture below Figure 1.

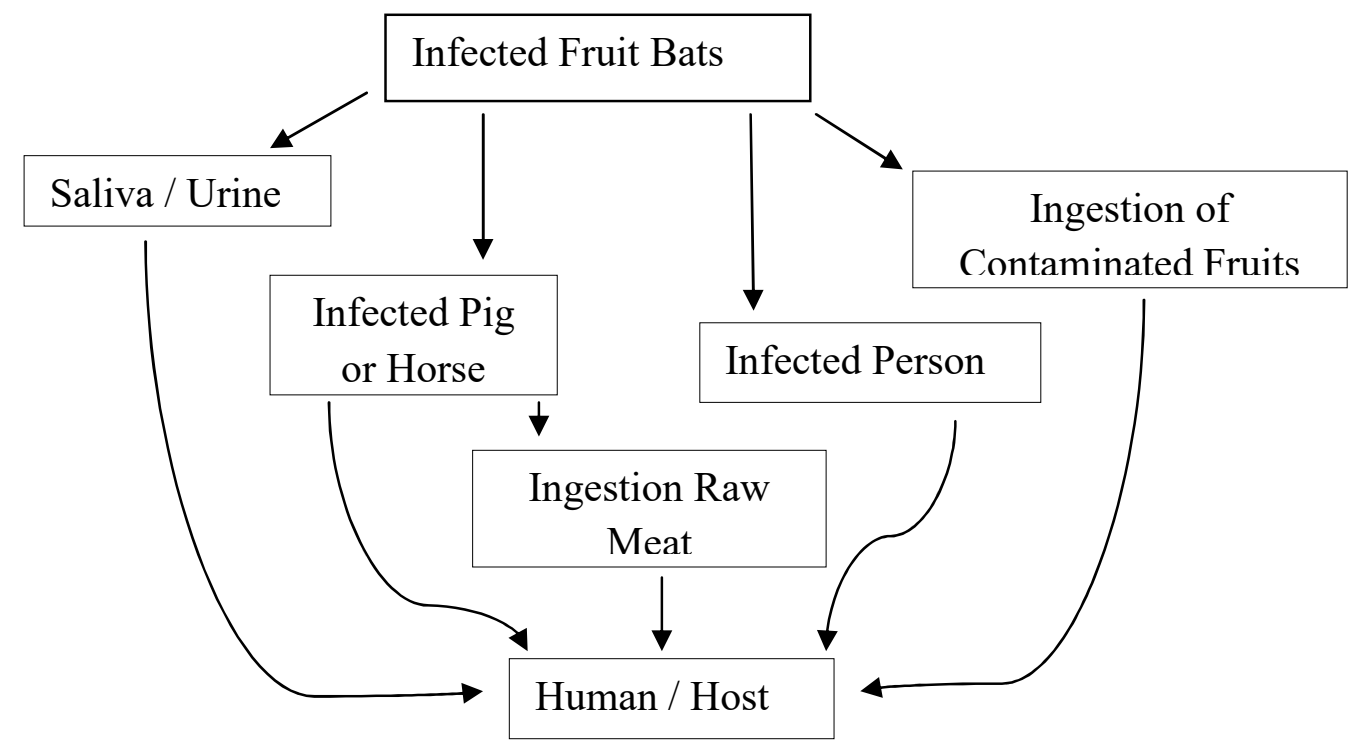

Figure 1: Various mode of Transmission of $\mathrm{NiV}$

\section{Clinical Conditions of NIV?}

The incubation period for $\mathrm{NiV}$ varies from 4-21 days [1]. The nonspecific symptoms like sudden onset of fever, headache, nausea, vomiting and myalgia were reported. The Common symptoms like fever, altered mental status, severe weakness, headache, respiratory distress, cough, vomiting, muscle pain, convulsion, diarrhea. About very few cases were reported meningismus. Severe neurological symptoms had occurred in $60 \%$ of cases, the infected patients after the symptomatic.

Nipah encephalitis was also reported about $20 \%$ cases. The nipah encephalitis includes tremors, areflexia, and segmental 
myoclonus was also observed. Fatigue and daytime somnolence reported that in 160 cases who survived NiV encephalitis, 7.5\% had relapses and 3.4\% showed late-onset encephalitis [17].

In general, the case-fatality rate is estimated at $40-75 \%$; however, this rate can vary between outbreaks and can be upto $100 \%$.

\section{Diagnosis of NIV?}

A high specificity for diagnosis of $\mathrm{NiV}$ was enzyme-linked immunoassay test (ELISA). Polymerase chain reaction (PCR) can also used to find the positivity [18]. Microinfarction was the major outcome of the report for 32 autopsies performed at Malaysian outbreak of NiV. Endothelial multinucleated syncytia and Fibrinoid necrosis were seen major blood vessels of the NiV victims [19].

Multiple asymmetric focal lesions were recorded by Magnetic resonance imaging (MRI) scans of patients with $\mathrm{NiV}$ [20-21].

\section{Treatment for NIV?}

$\mathrm{NiV}$ infections persist for last 4 decades but still there is no vaccine availed. The alarming condition was treatment options for patient's only supportive care. Previous study has reported ribavirin therapy shows a lower mortality rate [22]. The mortality rate has varied greatly in different outbreaks; in Bangladesh and West
Bengal show the high mortality rate of 100 $\%$ during the period of 2007-18.

\section{Future Prevention against NIV?}

The vaccination for $\mathrm{NiV}$ was still a query [23] along with there was no proper treatment options were available. Prevention is the major role to save the future by the following points;

1. The public should aware about the severity of the infection and mode of transmission of the infection of $\mathrm{NiV}$.

2. Domestic animals should properly monitor against the infections and not allowed to eat fruits that have been exposed to bats.

3. Bat-to-human transmission mainly taken by the fruits, ingestion of the raw palm sap should be avoided to reduce the risk of $\mathrm{NiV}$.

4. According to the National Centre of Disease Control of India has strongly advised about the hand hygiene by using soap and water after coming into contact with any sick person or domestic animal [24].

5. Past decades international governments and pharmaceutical companies formed the Coalition for Epidemic Preparedness Innovations (CEPI) to fund and promote research to provide the effective vaccine against the disease, during the period of Jan 2017 [24]. 


\section{CONCLUSIONS}

According to the current scenario both developed and developing countries $\mathrm{NiV}$ had a major outbreak with high mortality rate. However, Prevention and with proper education about the NiV which prevent the future outbreaks and mortality of the human kind.

\section{REFERENCES}

[1] Tan KS, Tan CT, Goh KJ: Epidemiological aspects of Nipah virus infection. Neurol J South East. 1999, 4:77-81.

[2] Chua KB, Goh KJ, Wong KT, et al.: Fatal encephalitis due to Nipah virus among pig-farmers in Malaysia. Lancet. 1999, 354:1257-1259. 10.1016/S01406736(99)04299-3

[3] Chua KB: Nipah virus outbreak in Malaysia. J Clin Virol. 2003, 26: 265275. 10.1016/s1386-6532(02)00268-8

[4] Chua KB, Bellini WJ, Rota PA, et al.: Nipah virus: a recently emergent deadly paramyxovirus $\quad$ Science. 2000, 288:1432-1435. 10.1126/science. 288. 5470.1432

[5] Ching PK, de los Reyes VC, Sucaldito MN, et al:: Outbreak of henipavirus infection, Philippines, 2014. Emerg Infect Dis. 2015, 21:328-331. 10.3201/eid2102.141433

[6] India beat one of the world's deadliest viruses - and made a music video about it. (2018). Accessed: 8 August, 2018: https:// www.npr.org/ sections/ goatsandsoda /2018/07 /01/622618912/ india-beat-one-of-theworlds-deadliestviruses-and-mad....

[7] NIPAH virus disease guidelines. (2018). Accessed: August 8, 2018: http://www.ncdc.gov.in/index4.php?lan $\mathrm{g}=1 \&$ level=0\&linkid=113\&lid=228.

[8] Wang LF, Broder CC: Henipaviruses. The Springer Index of Viruses. Tidona C, Darai G (ed): Springer, New York; 2011. 1119-1125. 10.1007/978-0-38795919-1_181

[9] Chua KB, Koh CL, Hooi PS, et al.: Isolation of Nipah virus from Malaysian island flying-foxes. Microbes Infect. 2002, 4:145-151. 10.1016/s12864579(01)01522-2

[10] Mackenzie JS, Chua KB, Daniels PW, et al.: Emerging viral diseases of Southeast Asia and the Western Pacific. Emerg Infect Dis. 2001, 7:497-504. 10.3201/eid0707.017703

[11] Yob JM, Field H, Rashdi AM, et al.: Nipah virus infection in bats (order Chiroptera) in peninsular Malaysia. Emerg Infect Dis. 2001, 7:439-441. 10.3201/eid0703.010312

[12] Goh KJ, Tan CT, Chew NK, et al.: Clinical features of Nipah virus encephalitis among pig farmers in 
Malaysia. N Engl J Med. 2000, 342:1229-1235.

\subsection{6/NEJM200004273421701}

[13] Negrete OA, Wolf MC, Aguilar HC, et al.: Two key residues in ephrinB3 are critical for its use as an alternative receptor for Nipah virus. PLoS Pathol. 2006, 2: 7.

10.1371/journal.ppat.0020007

[14]Luby SP, Hossain MJ, Gurley ES, et al.: Recurrent zoonotic transmission of Nipah virus into humans, Bangladesh, 2001-2007. Emerg Infect Dis. 2009, 15:1229-1235.10.3201/eid1508.081237

[15]Luby SP: The pandemic potential of Nipah virus. Antiviral Res. 2013, 100: 38-43.10.1016/j.antiviral.2013.07.011

[16] Sejvar JJ, Hossain J, Saha SK, et al.: Long-term neurological and functional outcome in Nipah virus infection. Ann Neurol. 2007, 62: 235-242. 10.1002/ana. 21178

[17]Tan CT, Goh KJ, Wong KT, et al.: Relapsed and late-onset Nipah encephalitis. Ann Neurol. 2002, 51: 703-708. 10.1002/ana.10212

[18] Ong KC, Wong KT: Henipavirus encephalitis: recent developments and advances. Brain Pathol. 2015, 25:605613. $10.1111 /$ bpa. 12278

[19]Looi LM, Chua KB: Lessons from the Nipah virus outbreak in Malaysia. Malays J Pathol. 2007, 29: 63-73.

[20]Lim CC, Sitoh YY, Lee KE, Kurup A, Hui F: Meningoencephalitis caused by a novel paramyxovirus: an advanced MRI case report in an emerging disease. Singapore Med J. 1999, 40:356-358.

[21] Sarji SA, Abdullah BJ, Goh KJ, Tan CT, Wong KT: MR imaging features of Nipah encephalitis. Am J Roentgenol. 2000, 175: 437-442.

\subsection{4/ajr.175.2.1750437}

[22] Chong HT, Kamarulzaman A, Tan CT, et al:: Treatment of acute Nipah encephalitis with ribavirin. Ann Neurol. 2001, 49: 810-813. 10.1002/ana.1062

[23] Satterfield BA, Dawes BE, Milligan GN: Status of vaccine research and development of vaccines for Nipah virus. Vaccine. 2016, 34: 2971-2975. 10.1016/j.vaccine.2015.12.075

[24] Ramphul K, Mejias S G, Agumadu V C, et al. (August 21, 2018) The Killer Virus Called Nipah: A Review. Cureus 10(8):e3168. DOI 10.7759/cureus.3168. 